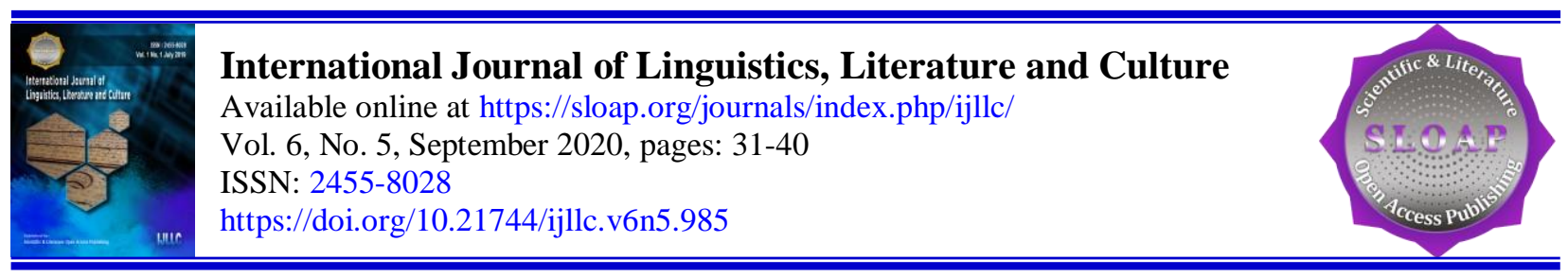

\title{
The Ability to Speak Indonesian through the Seminar Method
}

I Nyoman Juniardianta ${ }^{a}$

Article history:

Submitted: 09 May 2020

Revised: 18 June 2020

Accepted: 27 July 2020

\section{Keywords:}

education;

seminar method;

seminar;

society;

speaking Indonesian;

\begin{abstract}
In Indonesian lessons, 4 areas must be studied including listening, speaking, writing, and reading. In social terms, people need speaking skills, especially speaking skills in Indonesian well. Speaking Indonesian correctly is not only needed in social society but also needed in the world of work after graduating in the world of education. The objectives of this study are (1) to find out how the Indonesian language skills of grade VIIIA students of SMP Dharma Praja Denpasar in applying the seminar method (2) to find out what mistakes occur when speaking Indonesian at Dharma Praja Middle School for the implementation of the seminar. Based on the results of this study it can be concluded that the results of speaking of eighth-grade students of SMP Dharma Praja through the seminar method on the assessment that $95 \%$ of students can achieve grades even exceeding the KKM value of 76. Especially in the section of diction and grammar, the value of students is 100,72 students who got a value of 100 , namely 27 people who are included in the predicate very good, students who get a value of 72 , namely 3 people who are included in the predicate enough.
\end{abstract}

International journal of linguistics, literature and culture (c) 2020. This is an open access article under the CC BY-NC-ND license (https://creativecommons.org/licenses/by-nc-nd/4.0/).

\section{Corresponding author:}

Juniardianta, I.N.

Mahendradatta University, Denpasar, Indonesia

Email address: juniardianta1991@gmail.com

${ }^{a}$ Mahendradatta University, Denpasar, Indonesia 


\section{Introduction}

Indonesian comes from the Malay language, including the Austronesian language family that has been used as the lingua franca in the archipelago since the early centuries of the modern calendar, at least in its informal form. The form of colloquial language is named by the term Malay market (Atli \& Bergil, 2012; Yalçınkaya et al., 2009; Afshar \& Rahimi, 2014). This type is very flexible because it is very easy to understand and expressive, with a very large error tolerance and easy to absorb other terms from various languages used by its users. Indonesian was declared the position of the State language on August 18, 1945, as seen in the 1945 Constitution, which states that the State language is Indonesian (Aleka, 2011). Communication tools have a variety of forms, there are communication tools in the form of vocal sounds, there are also communication tools in the form of sounds but not vocals (for example the sound of whistles, kentongan, sirena, etc.), and there are also communication tools that are not in the form of sound (such as hand movements, heads, traffic lights, or other signs), (Arnawa, 2008). Writing is a copy of the language. Writing solely serves to preserve speech. The grammar (spelling) system does not regulate language. Writing is not like language.

There are many interesting methods so that students can easily and do not feel bored in learning Indonesian lessons and understand how to speak Indonesian more quickly. This reality, researchers are interested in improving the ability to speak Indonesian through the speech method, especially junior high school students. Researchers only focused on the results of observations from class VIIIA at SMP Dharma Praja. Based on the observations of researchers, most of the eighth-grade students of SMP Dharma Praja can speak Indonesian under the KKM or below the value of 76, therefore it still needs to be improved again. There are several factors about the students' low ability to speak Indonesian correctly, namely the lack of students paying attention to Indonesian lessons. Based on the background of the problems described above, the problems in this study can be formulated (1) How is the ability to speak Indonesian in class VIIIA SMP Dharma Praja through the seminar method (2) What are the mistakes that often occur when students speak Indonesian through the seminar method.

\section{Theoretical Basis}

Speaking is the ability to pronounce articulate sounds or words to express, express, and convey thoughts, ideas, and feelings. As an extension of this limitation, it can be said that speaking is a system of signs that can be heard (audible) and visible (visible) which utilizes some muscles and muscle tissue of the human body for the purpose and purpose of ideas or ideas that are more combined. furthermore, speaking is a form of human behavior that makes use of physical, psychological, neurological, semantic, and linguistic factors, so extensively, so widely that it can be considered the most important human tool for social control. Thus speaking is more than just the pronunciation of sounds or words. Speaking is a tool to communicate ideas that are compiled and developed according to the needs of the listener or listener (Ekasriadi, 2006).

\section{Basic Concepts of Speaking}

The ability to speak, express intentions and feelings verbally, has been learned and probably already possessed by students before they enter school. The level of students' speaking ability varies from good or fluent, moderate, stuttering, or less. Some students fluently express wishes, feelings of joy, sadness, pain, or fatigue (Tarigan, 2008; Khan \& Ali, 2010; Afshar \& Rahimi, 2016). It might even be able to express itself efficiently. Some other students were still afraid to speak that was heard by all their friends or in front of many people. The above should be used as a basis for teaching speaking in schools. Also, teaching speaking must be based on the basic concept of speaking as a means of communication and some other foundations. In this regard, the following will be elaborated on the basic concepts of speaking. Ekasriadi (2006), the basic concept of speaking as a means of communication includes nine things, namely as follows. 1. Speaking and listening are two reciprocal activities 2. Talking is the process of communicating individuals 3 . Talking is a creative expression 4 . Talking is behavior 5. Talking is a learned behavior 6. Talking is influenced by a wealth of experience 7. Speaking of means broadens the horizon 8 . Linguistic and environmental abilities are closely related to 9 . Talking is a personal eminence. 


\section{Speaking Preparation}

In outline, the preparations made for an oral composition are the same as preparing a written composition. In this case, the speaker usually faces a time that he knows beforehand. The preparations for the presentation can be seen in the following steps as quoted from Aleka, 2011):

Researching problems include (1) Determine the intent (2) Analyze the listener and situation and (3) Select and submit topics. Prepare a description including (1) Gather ingredients (2) Outline the description and (3) Describe in detail. Carry out exercises covering (1) Practice in a loud voice (2) Practice with movement and (3) Practice with facial expressions.

The aspects of using Indonesian when speaking in formal situations: Using a standard language (Standard) means that the language used must be following the language that is commonly used by people. Using language appropriate to the level of education and ability of the audience, meaning that a speaker must be able to distinguish who is the interlocutor or audience so that the language used is adjusted to make it understandable.Using language that does not offend the listener or audience effective language using terms relevant to the topic discussed Pay attention to information or messages that are correct and useful for the listener or audience (Aleka, 2011). Oral interactions can be characterized by routines which are conventional ways of presenting information that can focus on information or interactions. These information routines contain types of information structures that often appear either expository (such as narrative, description, instruction, and comparison) or evaluative (such as explanation, justification, prediction, and decision). Interaction routines can be services (job interviews, for example) or social (dinner parties for example). This difference between information and interaction routines reflects the difference between transactional and interactional (or interpersonal). Another characteristic of interaction is that participants need to negotiate meaning (Azies \& Alwasilah, 1996).

\section{Kinds of Talking}

Ekasriadi (2006) there are at least five bases used in classifying speech. The five foundations are (1) Speak according to the situation (2) Speak on purpose (3) Speak according to the method of delivery (4) Speak according to the number of listeners (5) Speak based on special events Formal conversation takes place in formal situations. The language used is standard language and can be understood in general (Almindatifa: 2011). Common types of speech are (1) Lecture (2) Planning (3) Interview (4) Parliamentary procedure (5) Tell a story. The assessment criteria for the speaking aspect include (1) Fluency in speaking (2) Intonation (3) Pronunciation (4) Choice of words and (5) Grammar.

\section{Understanding Seminar}

The understanding seminar is a meeting of a group of people held to discuss a problem and find a scientific solution to the problem. Another opinion says that the meaning of a seminar is a meeting held by a group of people to discuss a particular topic and find solutions to problems employing question-and-answer interaction (Barekat \& Mohammadi, 2014; Brice et al., 2008). Etymologically, the word seminar comes from the Latin "seminarium" which means "land for planting seeds". But of course, the word is not defined literally, but rather as a form of academic teaching carried out by a university or organization. From the explanation of the meaning of the seminar, it can be concluded that the seminar activities are a meeting held with a certain technical, a meeting that is mass in nature or is followed by many people, a meeting full of information and learning, a meeting that involves a scientific discussion process and is beneficial for many parties, in terminology, a seminar is an activity carried out by an expert or researcher to deliver or present a scientific work to the participants, which is useful in terms of helping make decisions. Understanding Seminar According to Experts. Webster's Dictionary of Unabridged Rusland Ahmadi Seminar is one of the activities that can be carried out as a process to solve a problem or the process of finding a solution that is usually based on the results of a study of literature. Seminar Objectives To exchange information from one person (resource person) with others to be developed into something broader and more useful. Seminar Requirements Seminar members or participants can think logically about how to solve problems. The speaker already knows the problems to be conveyed. Determine the time. The problem has been formulated.

Problems can be solved systematically and scientifically. Characteristics of the Seminar In the form of a forum is generally a seminar activity in the form of an interaction forum involving a number of audiences so that two-way

Juniardianta, I. N. (2020). The ability to speak Indonesian through the seminar method. International Journal of Linguistics, Literature and Culture, 6(5), 31-40. https://doi.org/10.21744/ijllc.v6n5.985 
communication occurs on the material presented. Referring to Papers, namely discussion of seminar material referring to papers or work papers that have been compiled and presented by the speakers. Discussing Scientific Issues, that is, every seminar activity always raises actual scientific issues as material for discussion.

There is a response from the audience, which means that in the seminar, the main objector (usually an expert) will be given priority to respond to the contents of the paper presented by the speaker. Furthermore, the audience is also allowed to participate in giving their opinions. Seminar function to convey the main idea or something new to the general public or seminar participants (Ahmad \& Zuhdi, 2002; Arnawa, 2008; Fauzi, 2011). It is hoped that the participants who follow it can gain new knowledge and knowledge which can later be developed again to solve problems. As one of the conditions for obtaining a certificate aimed at obtaining recognition or qualification in work. A place to seek knowledge. A place to add relationships, friends, network. Adding a portfolio. Increase selfconfidence. One way to socialize in official forums (https://sarjanaekonomi.co.id/seminar/)

\section{Characteristics of the Seminar}

Seminars have special characteristics that differentiate them from other discussion activities. Referring to the definition of a seminar, the characteristics of seminar activities are as follows the form of a forum; In general, seminars take the form of an interactive forum that involves some audiences so that two-way communication occurs on the material presented. Referring to Papers; discussion of seminar material refers to the papers or papers that have been prepared and presented by the speakers. Discuss Scientific Issues; every seminar activity always raises actual scientific issues as material for discussion. There is a response from the audience; In the seminar, the main contributor (usually an expert) will be given priority to respond to the contents of the paper presented by the speaker. Furthermore, the audience is also allowed to participate in giving their opinions.

\section{Seminar Objectives and Functions}

The purpose of the seminar is to convey an opinion or something new to the participants. That way, the seminar participants get new information that can be developed into something broader to the public. The function of the seminar in general is as a medium for conveying information or new ideas of a scientific nature to the public. That way, participants can use this information to solve existing problems. Each seminar activity generally ends with a conclusion and a solution to the problems discussed. The solution can be applied by seminar participants in their lives, both directly and indirectly. Seminar participants will usually get a certificate, which is proof that they already have new knowledge and knowledge in a certain field. This certificate can be an additional qualification for a person's competence, both in the world of work and professionalism.

Parties Involved in the Seminar Seminar activities can be carried out in the cooperation of several parties involved in it. The parties involved in the seminar are as follows, Master of Ceremony; that is, those who open the seminar, introduce presenters, introduce moderators and minutes, and close seminar activities. Moderator; namely the party responsible for the running of the seminar. Speakers; that is the party presenting seminar material to participants. Usually, the speaker is someone who is an expert in a certain field. Audience; ie seminar participants who listened to the seminar material and responded to the contents of the material. Minutes; namely the party responsible for recording and summarizing important matters in the discussion of seminar material. Seminar Elements.

1) Material Covered

Where this material is the core of the seminar. The material can be in the form of scientific papers, scientific articles, or other forms of scientific writing.

2) There is a Moderator

This moderator is different from the presenter. This moderator is the seminar speaker. The moderator can be the owner of the scientific work or someone who is an expert in the scientific field.

3) There are minutes or note-takers

The results of the notes are written in the form of minutes.

4) Rebuttal

This rebuttal comes from seminar participants who want to ask questions related to the material presented.

5) Any Issues Addressed

This problem stems from the seminar material. This problem is the main ingredient, so it will be used as a material to ask questions. This problem can be used as a persuasive seminar title. 
6) There is a Solution

Solutions are the answers that you will get when you attend this seminar. The conclusions you get can become a new science.

7) There is a certificate

This is proof that you have attended a seminar. In addition, the purpose of this certificate is proof that you have acquired new knowledge.

This knowledge will be in addition to your professional qualification. For students, it can be used as a competency qualification in applying for a job.

Seminar Arrangement

Chief Executive Report

Chairperson presentation

Discussion by the speaker

Discussion or question and answer

Conclusion

Closing

\section{Materials and Methods}

As long as students speak in front of the researcher assesses diction and grammar. After knowing the results of diction and grammar, the researcher recorded students' scores on the application of the seminar method when speaking Indonesian correctly, especially in diction and grammar. As for the steps in the process of applying the seminar method to students, the researcher gives an assignment to students to create groups with Indonesian language assignments.

\section{Results and Discussions}

In the system of analyzing the ability to speak Indonesian students through indirect methods are given a standard score. The score given is a temporary nature called the raw score. In giving the raw score usually moves between 0 10 , then in giving the raw score there is no absolute limitation. The raw score obtained by students in a test cannot provide a clear picture of student achievement on the test. For example, if we know that a student in a speaking test using the oratory method achieves a score of 67 without other information, we cannot interpret whether the student is achieving good, moderate, or poor performance (Nurkancana \& Sunarta, 1992).

\section{Data Collection and Analysis Techniques in Research}

Collecting data in a study is a very important stage. Correct and correct data collection techniques will produce data that has high credibility, and vice versa. Therefore, at this stage, it cannot be wrong and must be carried out carefully following the procedures and characteristics of the research to be used. In research, errors or imperfections in data collection methods will have fatal consequences, namely in the form of data that is not credible, so that the results the research cannot / cannot be justified for its accuracy. In changing the raw score and standard score, the steps that must be followed are: Determine the ideal maximum score (SMI) The ideal maximum score is the highest number of scores obtained based on the assessment guidelines. Create conversion guidelines A conversion guideline used in converting raw scores into standard scores using the absolute norm on a hundred scale. The hundred are also called percentiles. To convert the raw score into a standard score with absolute norms on a hundred scale, the following formula is used.

$$
P=\frac{x}{S M I} x 100
$$

Juniardianta, I. N. (2020). The ability to speak Indonesian through the seminar method. International Journal of Linguistics, Literature and Culture, 6(5), 31-40. https://doi.org/10.21744/ijllc.v6n5.985 
Annotation:

P: Percentile

$\mathrm{X}$ : Score obtained

SMI: Maximum ideal score

(Nurkancana \& Sunarta, 1992).

For example, a test follower gets a raw score of 11, then the standard score of the test follower can be calculated as follows

$$
\begin{aligned}
P & =\frac{x}{S M I} \times 100 \\
& =\frac{11}{17} \times 100 \\
& =64
\end{aligned}
$$

The results of the researcher's observations on the Indonesian language skills of class VIIIA students of SMP Dharma Praja are as follows, to determine the level of Indonesian language proficiency, the minimum completeness criteria (KKM) used in Indonesian language lessons are 76. The following table is used to determine the predicate criteria. Qualification score:

1) 86-100 EXCELLENT

2) $76-85 \mathrm{GOOD}$

3) $60-75$ ENOUGH

4) $<60$ LESS

(Student report card class VIII SMP Dharma Praja)

Based on the results obtained by researchers in the class when carrying out learning to speak Indonesian, grade VIIIA students when applying the seminar method, namely in the table as follows;

Table 1

Scores of class VIIIA students in speaking Indonesian when applying the seminar method

\begin{tabular}{llll}
\hline Student's Name & Diction & Grammar & Raw Score \\
\hline S 1 & 10 & 8 & 18 \\
S 2 & 10 & 8 & 18 \\
S 3 & 10 & 8 & 18 \\
S 4 & 10 & 8 & 18 \\
S 5 & 10 & 8 & 18 \\
S 6 & 10 & 8 & 18 \\
S 7 & 5 & 8 & 13 \\
S 8 & 10 & 8 & 18 \\
S 9 & 10 & 8 & 18 \\
S 10 & 10 & 8 & 18 \\
S 11 & 10 & 8 & 18 \\
S 12 & 5 & 8 & 13 \\
S 13 & 5 & 8 & 13 \\
S 14 & 10 & 8 & 18 \\
S 15 & 10 & 8 & 18 \\
S 16 & 10 & 8 & 18 \\
S 17 & 10 & 8 & 18 \\
S 18 & 10 & 8 & 18 \\
S 19 & 10 & 8 & 18 \\
S 20 & 10 & 8 & 18 \\
S 21 & 10 & 8 & 18 \\
\hline
\end{tabular}




\begin{tabular}{llll}
\hline S 22 & 10 & 8 & 18 \\
S 23 & 10 & 8 & 18 \\
S 24 & 10 & 8 & 18 \\
S 25 & 10 & 8 & 18 \\
S 26 & 10 & 8 & 18 \\
S 27 & 10 & 8 & 18 \\
S 28 & 10 & 8 & 18 \\
S 29 & 10 & 8 & 18 \\
S 30 & 10 & 8 & 18 \\
\hline
\end{tabular}

Code $\mathrm{S}=$ Student

Table 2

Consideration of direction errors and grammar in assessing Indonesian speaking ability after conducting the seminar method in class VIIIA students of SMP Dharma Praja

\begin{tabular}{cl}
\hline Number of students who make errors of diction & $\begin{array}{l}\text { The number of students who are doing mistakes } \\
\text { in language settings }\end{array}$ \\
\hline 2 & 0 \\
\hline
\end{tabular}

The raw score will be converted into a standard score. The results of the scoring in the data processing above are still in the form of raw scores and the scores must be changed in the form of standard scores so that real results can be obtained. To convert the raw score into a standard score formula is used.

$$
P=\frac{x}{S M I} x 100
$$

Based on this formula, the standard score of each student's mastery can be calculated as follows. Given the number of aspects that are inside. Which in this study is 2 with a maximum weight of diction (10), sentence structure (8) then the SMI is $10+8=18$. Students who get the highest score, with a score of 18 , then the standard score is:

$$
\begin{aligned}
P & =\frac{x}{S M I} \times 100 \\
& =\frac{18}{18} \times 100 \\
& =100
\end{aligned}
$$

Students in second place with a score of 13 , the standard scores are:

$$
\begin{aligned}
P & =\frac{x}{S M I} \times 100 \\
& =\frac{13}{18} \times 100 \\
& =72
\end{aligned}
$$

Thus, the calculation is carried out for all standard scores of each student, to obtain a clearer picture of the results of the study above will be explained, Vulnerable each score is based on the level of competence VIIIA class and vulnerable scores of each aspect of assessment based on the level of difficulty of each aspect assessment and level of mastery. The guidelines for the conversion of the level of mastery of diction and sentence structure in speaking Indonesian are as follows. From the level of mastery of this aspect, it can be seen the results of the level of mastery

Juniardianta, I. N. (2020). The ability to speak Indonesian through the seminar method. International Journal of Linguistics, Literature and Culture, 6(5), 31-40. https://doi.org/10.21744/ijllc.v6n5.985 
in students in analyzing the ability to speak Indonesian through the seminar method, the following table of the raw scores and standard scores, and their predicates.

Table 3

The final score of class VIIIA students in speaking Indonesian before using the speech method

\begin{tabular}{llll}
\hline $\begin{array}{l}\text { Student's } \\
\text { code }\end{array}$ & Raw score & $\begin{array}{l}\text { Standard } \\
\text { score }\end{array}$ & Predicate \\
\hline S 1 & 18 & 100 & Very good \\
S 2 & 18 & 100 & Very good \\
S 3 & 18 & 100 & Very good \\
S 4 & 18 & 100 & Very good \\
S 5 & 18 & 100 & Very good \\
S 6 & 18 & 100 & Very good \\
S 7 & 13 & 72 & Sufficient \\
S 8 & 18 & 100 & Very good \\
S 9 & 18 & 100 & Very good \\
S 10 & 18 & 100 & Very good \\
S 11 & 18 & 100 & Very good \\
S 12 & 13 & 72 & Sufficient \\
S 13 & 13 & 72 & Sufficient \\
S 14 & 18 & 100 & Very good \\
S 15 & 18 & 100 & Very good \\
S 16 & 18 & 100 & Very good \\
S 17 & 18 & 100 & Very good \\
S 18 & 18 & 100 & Very good \\
S 19 & 18 & 100 & Very good \\
S 20 & 18 & 100 & Very good \\
S 21 & 18 & 100 & Very good \\
S 22 & 18 & 100 & Very good \\
S 23 & 18 & 100 & Very good \\
S 24 & 18 & 100 & Very good \\
S 25 & 18 & 100 & Very good \\
S 26 & 18 & 100 & Very good \\
S 27 & 18 & 100 & Very good \\
S 28 & 18 & 100 & Very good \\
S 29 & 18 & 100 & Very good \\
S 30 & 18 & 100 & Very good \\
\hline & &
\end{tabular}

Code $\mathrm{S}=$ Student

Based on the value above, it shows that the results of the ability to speak Indonesian through the seminar method for class VIIIA students, namely 95\% exceed the minimum completeness criteria for Indonesian language lessons, namely 76. Most of the students' ability scores in speaking Indonesian through the seminar method are dominated by categories at a very good level. The balance of the predicate value of the results of the students' speaking ability in Indonesian will be outlined in Table 4 .

Table 4

The results of the students' speaking ability in Indonesian

\begin{tabular}{llll}
\hline No & Score & Predicate & Total Student \\
\hline 1. & 100 & Very good & 27 \\
2. & 72 & sufficient & 3 \\
\hline
\end{tabular}


After knowing the results of speaking scores in Indonesian students through the seminar method which is almost mostly above the KKM.

\section{Conclusion}

Based on the results of these studies it can be concluded that the results of using the seminar method in analyzing the ability to speak Indonesian students of class VIIIA SMP Dharma Praja namely 95\% of students can pass the KKM score of 76. Especially in the section of diction and grammar, the value of students is 100, 72 students who got a score of 100, which is 27 people who are included in the predicate very good, students who get a value of 72, namely 3 people who are categorized as sufficient. Based on the above conclusions, suggestions can be made. In the Indonesian language learning process, the teacher is expected to apply the seminar method in speaking Indonesian for class VIIIA students of SMP Dharma Praja. It is intended that students do not feel bored in Indonesian lessons.

Conflict of interest statement

The author declared that he has no competing interest.

Statement of authorship

The author has responsibility for the conception and design of the study. The author has approved the final article.

Acknowledgments

I am grateful to two anonymous reviewers for their valuable comments on the earlier version of this paper.

Juniardianta, I. N. (2020). The ability to speak Indonesian through the seminar method. International Journal of Linguistics, Literature and Culture, 6(5), 31-40. https://doi.org/10.21744/ijllc.v6n5.985 


\section{References}

Afshar, H. S., \& Rahimi, M. (2014). The relationship among critical thinking, emotional intelligence, and speaking abilities of Iranian EFL learners. Procedia-Social and Behavioral Sciences, 136, 75-79.

Afshar, H. S., \& Rahimi, M. (2016). Reflective thinking, emotional intelligence, and speaking ability of EFL learners: Is there a relation?. Thinking Skills and Creativity, 19, 97-111. https://doi.org/10.1016/j.tsc.2015.10.005

Ahmad, R. U., \& Zuhdi, D. (2002). Pendidikan bahasa dan sastra indonesia di kelas tinggi. Malang: Universitas Negeri Malang.

Alek, A. (2011). Bahasa Indonesia untuk perguruan tinggi. Prenada Media.

Arnawa, N. (2008). Wawasan Linguistik dan Pengajaran Bahasa.

Atli, I., \& Bergil, A. S. (2012). The effect of pronunciation instruction on students' overall speaking skills. ProcediaSocial and Behavioral Sciences, 46, 3665-3671. https://doi.org/10.1016/j.sbspro.2012.06.124

Barekat, B., \& Mohammadi, S. (2014). The contribution of the teachers' use of dialogic discourse pattern to the improvement of the students' speaking ability. Procedia-Social and Behavioral Sciences, 98, 353-362. https://doi.org/10.1016/j.sbspro.2014.03.426

Brice, J. H., Travers, D., Cowden, C. S., Young, M. D., Sanhueza, A., \& Dunston, Y. (2008). Health literacy among Spanish-speaking patients in the emergency department. Journal of the National Medical Association, 100(11), 1326-1332. https://doi.org/10.1016/S0027-9684(15)31512-1

Ekasriadi, IAA. (2006). Bahan Kuliah Berbicara I.IKIP PGRI BALI.

Fauzi, A. (2011). Pintar Bahasa Indonesia pengetahuan Sastra dan Tata Bahasa. Bandung: Mahir Sindo Utama.

Furqanul, A., \& Chaedar, A. (1996). Pengajaran Bahasa Komunikatif: Teori dan Praktek. Remaja Rosda Karya. Bandung.

Khan, N., \& Ali, A. (2010). Improving the speaking ability in English: The students' perspective. Procedia-Social and Behavioral Sciences, 2(2), 3575-3579. https://doi.org/10.1016/j.sbspro.2010.03.554

Nurkancana, W., \& Sunartana, P. P. N. (1990). Evaluasi hasil belajar. Surabaya: Usaha Nasional.

Pala, R. (2014). Teori kode-kode berbicara. INSANI, ISSN, 977-240.

Tarigan, H. G. (2008). Berbicara sebagai suatu ketrampilan berbahasa. Bandung: Angkasa, 16.

Yalçınkaya, F., Muluk, N. B., \& Şahin, S. (2009). Effects of listening ability on speaking, writing and reading skills of children who were suspected of auditory processing difficulty. International journal of pediatric otorhinolaryngology, 73(8), 1137-1142. https://doi.org/10.1016/j.ijporl.2009.04.022 